\title{
COVID-19 Pandemic: Stress and Psychiatric Disorders
}

\section{COViD-19 Pandemisi: Stres ve Psikiyatrik Bozukluklar}

(i) İsmet KIRPINAR

Bezmialem Vakıf University Faculty of Medicine, Department of Psychiatry, İstanbul, Turkey

\begin{abstract}
The epidemic, which first started as viral pneumonia in Wuhan, China at the end of 2019 and is now known as Coronavirus disease-19 (COVID-19), rapidly spread to almost every part of the world and named a pandemic in March 2020. It is well known that psychiatric symptoms and syndromes, especially posttraumatic stress disorder, major depression, anxiety, and sleep disorders reach high prevalence values in natural or man-made disasters. Especially in infectious disease epidemics where mortality rates are high, patients, those who are quarantined, and the whole society experience very intense mental stress and trauma. It is not easy to avoid psychological distress after facing highly fatal illnesses such as Ebola, severe acute respiratory syndrome (SARS), or COVID-19. When pandemics turn into a rapid and global disaster, the prevalence values of mental problems reach even higher levels. Combating mental disorders not only provides psychological well-being but also affects the course of the epidemic, as these disorders can delay efforts to fight epidemics.

Mental health complaints increase in healthcare workers as a result of the stress and trauma of working during the epidemic. Studies report that during the SARS epidemic, approximately one-fifth of healthcare workers experienced 'significant mental disorders'. Medical professionals who develop mental disorders will be less productive, which will weaken the fight against the epidemic. Therefore, it is very important to support healthcare professionals.

Since the COVID-19 outbreak is a relatively recent disaster, epidemiological study results have not yet been published sufficiently. However, the results of serious epidemics caused by viruses such as SARS and Ebola have previously been published. In this review, information about the psychiatric morbidity expected after COVID-19 is reviewed in the light of the results of studies conducted mainly in previous virus epidemics.
\end{abstract}

Keywords: Mental disorder, epidemic, anxiety, depression, posttraumatic stress disorder (PTSD), COVID-19, SARS

\section{ÖZ}

İlk olarak 2019 yılı sonunda Çin'in Wuhan şehrinde bir viral pnömoni olarak başlayan ve şimdi Covid-19 olarak bilinmekte olan salgın, hızlıca dünyanın hemen her tarafına yayılarak Mart 2020?de pandemi niteliği kazanmıştır. Doğal veya insan eliyle gerçekleştirilen afetlerde başta travma sonrası stres bozukluğu, majör depresyon, anksiyete ve uyku bozuklukları olmak üzere psikiyatrik belirti ve sendromların yüksek prevalans değerlerine ulaştığı iyi bilinmektedir. Özellikle mortalite oranlarının yüksek olduğu enfeksiyon hastalığı epidemilerinde hastalar, karantinaya alınanlar ve bütün toplum çok yoğun bir ruhsal stres ve travma yaşarlar. Ebola, şiddetli akut solunumsal sendrom (SARS) veya COVID-19 gibi yüksek düzeyde ölümcül bir hastalıkla yüzyüze gelmek durumunda psikolojik distressten kaçınabilmeyi hayal etmek çok güçtür. Pandemiler hızlı ve global bir felakete dönüşürken, ruhsal sorunların prevalans değerleri daha da yüksek düzeylere ulaşmaktadır. Ruhsal bozukluklarla mücadele sadece psikolojik iyi oluşu sağlamakla kalmaz, bu bozukluklar salgın hastalıkla savaş çabalarını da geciktirebildiği için epideminin gidişini de etkiler. Salgın sırasında çalışmanın stres ve travmasının bir sonucu olarak sağlık çalışanlarında ruh sağlığı yakınmaları artar. Çalışmalar SARS salgını sırasında sağılı çalışanlarının yaklaşık beşte birinde "belirgin ruhsal bozukluklar" görüldüğünü bildirmektedir. Ruhsal bozukluk gelişen tıp profesyonelleri daha az üretken olacaklarından bu da epidemiyle mücadelenin zayıflamasına yol açacaktır. Bu yüzden özellikle sağlık çalışanlarının desteklenmesi önem arzetmektedir. COVİD-19 salgını görece yeni bir felaket olduğundan henüz epidemiyolojik çalışma sonuçları yeterince yayımlanmış değildir. Ancak SARS ve Ebola gibi virüslerin neden olduğu ciddi düzeydeki salgınlarla ilgili sonuçlar daha önce yayımlanmıştı. Bu derlemede, ağırlıklı olarak önceki virüs epidemilerinde yapılmış çalışma sonuçları ışı̆̆ında COVİD-19 sonrası beklenen psikiyatrik morbidite ile ilgili bilgiler gözden geçirilmektedir.

Anahtar Sözcükler: Ruhsal bozukluk, salgın, anksiyete, depresyon, travma sonrası stres bozukluğu (TSSB), COVID-19, SARS

Cite this article as: Kırpınar i. COVID-19 Pandemic: Stress and Psychiatric Disorders. Bezmialem Science. 2021;9(Supplement 1):61-68. 


\section{Introduction}

A new virus severe acute respiratory syndrome coronavirus-2 (SARS-CoV-2) from the CoV family emerged in Wuhan, the largest metropolitan city of China's Hubei province, in the last months of 2019. This virus was first reported at the end of the year by the World Health Organization (WHO) China Country Office and is now known as coronavirus-19 (COVID-19). The COVID-19 outbreak, which started as viral pneumonia, quickly spread to almost every part of the world and became a pandemic in March 2020. Pandemic is the general name given to epidemic diseases that spread and affect a wide area in more than one country or continent in the world. The feature that distinguishes pandemics from natural disasters is the lack of time and space limit and high morbidity/mortality rates. The inability to predict the duration of the situation or even whether it is preventable means more uncertainty and anxiety than other disasters.

Infectious diseases continue to be one of the most threatening conditions for human well-being. Despite great advances in medicine, outbreaks of these diseases are still among the most important causes of morbidity and mortality in both developed and developing countries (1). According to $\mathrm{WHO}$, viral diseases have become a serious threat to public health with emerging new viruses. Many viral epidemics have emerged in the last 20 years. SARS in 2003, influenza due to H1N1 (Swine flu) virus subtype in 2009, Middle East Respiratory Syndrome (MERS) in 2012, and Ebola virus disease in 2014 caused high morbidity and mortality rates. Each of these past outbreaks has led to the development of significant rates of psychiatric symptoms and disorders in those who are sick and in quarantine (2-4).

COVID-19 caused millions of people to become ill and hundreds of thousands of deaths around the world as of May 2020, when this review was prepared. With the spread of the virus, uncertainties and losses continue. It has created an unexpectedly large burden on the political, economic, and social security systems as well as the health systems as a result of its easy spread, the inability of the population to be immunized, the delay and insufficiencies in tests, the shortages of medical equipment and personnel, the delay and inadequacies in preventing contact with sick people (5). The severity of the disease, its unpredictable course and its consequences, the uncertainties, the need for distance and isolation, the failure of our conventional coping systems, and information pollution are at a level that may cause pessimism about the psychological effects of the emerging crisis. Initial observations suggest that the epidemic will leave a significant psychological sequel (6).

Since the COVID-19 outbreak is a relatively recent disaster, epidemiological study results have not yet been published sufficiently. However, results of serious outbreaks caused by associated coronaviruses, such as SARS and MERS, have previously been published $(2,7,8)$. In addition, in the past epidemics, results showing an increased risk for mental problems in healthcare workers because of increased workload, the need for personal protection, and the psychological effects of the possibility of infection for themselves and their families were also reported. Although the worldwide COVID-19 threat is not consistent with the data we have gathered from our previous experiences, the information can be a guide to the current coronavirus pandemic.

\section{Factors Related to the Psychological Dimensions of the Pandemics}

It is well known that natural disasters cause mental disorders such as posttraumatic stress disorder (PTSD), major depression, anxiety disorders, and sleep disorders (9). As contagious diseases at a pandemic level spread rapidly and turn into a global disaster, the prevalence rates of mental problems also reach much higher levels.

Psychiatric morbidity in those infected with coronavirus seems to be due to the interaction of many factors. It is clear that a situation known to be fatal can have psychologically traumatizing effects. Biological factors include direct effects of viral infection (including brain infections), cerebrovascular diseases, degree of physiological threat (such as hypoxia), immunological response, and medical interventions. In non-infected individuals, the most consistent risk factor reported in studies is increased contact with affected patients. Among other risk factors, a previous history of psychiatric and/or general medical symptoms/disorders, long time in quarantine, perception of insufficient organizational support, and perceived social stigma are important (10). Finally, the role of stress/traumatic experience created by encountering an unexpected, sudden, and uncertain situation should not be overlooked.

\section{Stress and Trauma}

As in every living organism, there is a dynamic state of internal balance (homeostasis) based on the interaction of many factors in human beings. This balance, which is created by the interaction of various destructive and protective biological, psychological, and social factors induces a state of excitement called stress when faced with threatening situations (stress factors). This arousal has psychological symptoms such as tension, restlessness, anger, and cognitive symptoms such as memory and attention problems, which are briefly defined as "fight or flight reaction" and are largely due to autonomic hyperactivity, adrenaline discharge, and hypothalamo-pituitary-adrenal axis activation (11). Many experts add "freezing" as the third form of reaction.

Undoubtedly, the severity and duration of the arousal and symptoms that occur differ depending on the stress factor and many individual features. Individuals who encounter the stress factor may have different ways of perceiving and coping with the situation. The same event does not elicit the same reactions in every individual, while an individual finds the event quite stressful, it can be seen as a small problem for another individual (12). However, threats to physical or mental integrity cause stress in almost everyone. The severity and long duration of the stress factor lead to the persistence of the arousal and symptoms that occur.

Although "trauma" is generally used for events with a high stressor effect in colloquial language, the key concept is that it is 
a severe event that exceeds the person's ability to cope. Although the difference between the concepts of stress and trauma is not very clear, trauma is generally understood as extreme helplessness and weakness and important situations that cause horror (13). These are experiences that threaten the life, body integrity, or mental health of the individual. A wide range of events that can shake the individual's basic beliefs about himself, the world, and others can be perceived as "traumatic". Processes that are deemed to have traumatic effects need not only be directed at the person but witnessing such an event experienced by someone else is also considered traumatic (14). The first reaction to this type of trauma is usually shocking; When a person is in shock, he both freezes and tends to deny the event as if it had not happened. KüblerRoss (15) conceptualized a 5-stage trauma response that includes the stages of shock, (denial, anger, bargaining, depression, and acceptance) following a person is exposed to trauma. Kübler-Ross (15) stated that the last stage is not a "happy end", it involves various emotions, and this stage was defined by a patient as "the last rest before a long journey". Traumatic events or situations almost always play a triggering role for serious mental disorders and sometimes they directly cause mental disorders.

As with many events and situations that lead to psychological trauma, infectious disease outbreaks are sudden, overwhelming, and create feelings of helplessness, weakness, and guilt. People need to perceive the world as a safe place. This perception is important for people to feel safe and events are under control. Outbreaks are situations that shake people's perceptions, expectations, and the assumption that the world is reliable. In such cases, besides the loss of loved ones, relatives, or irreplaceable assets, the normal coping capacity of the person is destroyed, and a threat arises that compels emotional, cognitive, behavioral, and even religious/cultural beliefs. A study comparing SARS patients with healthy controls using the Perceived Stress scale found that stress rates were very high in patients, which was significantly associated with negative psychological effects. $25 \%$ of the patients later requested psychological follow-up (16). Again a study with SARS patients in 2003 found that even 1 year after the epidemic, patients continued to complain of high stress levels and psychological disturbances to be worried (17). In addition to anxiety, hopelessness, irritability, anger feelings, physical complaints such as fatigue, pain, and sleep disorders are common in people exposed to disasters (10). Depression and anxiety disorders are at least twice as common as usual crisis experiences (18).

\section{Quarantine and Isolation}

Quarantine is the separation and restriction of movement of people potentially exposed to an infectious disease to make sure they are well and to reduce their risk of infecting others. This definition is different from isolation, which means separating people diagnosed with an infectious disease from people who have not yet been diagnosed. However, these two definitions are often used interchangeably (5).

Separation from families and society with prolonged isolation has significant effects on individuals even if they do not get the disease and are only isolated. Similar effects were observed in healthcare workers working in isolation. Especially in epidemics where mortality rates are high, those who are quarantined as well as patients experience very intense mental tension. It is not easy to avoid psychological distress when faced with being infected with a highly fatal disease such as Ebola, SARS, or COVID-19.

The photo taken by Daniel Berehulak for The New York Times during the epidemic from the Ebola treatment center in Liberia which won the Pulitzer Prize highlights the situation more strongly than numerical data: "They meet and fear the officers wearing spacesuits they have never seen before. They are waiting for their test results, their next medical exam, their symptoms to appear or disappear. They are watching which ones in the canopy in the courtyard are getting better and which are sick. They are praying" (19).

Quarantine is almost always an uncomfortable experience. Separation from loved ones, loss of freedom, uncertainty about illness, and boredom can have dramatic effects. Suicides, serious anger attacks, and forensic events have been reported during quarantine in previous outbreaks $(20,21)$. The anticipated potential benefits from quarantine against possible psychological costs should be carefully calculated (22). The success of quarantine which is a public health measure depends on keeping it as short as possible, taking into account its negative effects.

A study of healthcare workers who were quarantined due to the possibility of having contact with SARS showed a high risk for acute stress disorder (ASD) (23). Many quantitative studies reported higher rates of general psychological symptoms, depression, stress, low mood, post-traumatic stress symptoms, anger, burnout syndrome, anxiety, insomnia, irritability, and difficulty concentrating compared to those who were not quarantined. Another study reported that $29 \%$ of those quarantined for SARS showed signs of PTSD and 31\% depression. In addition, staying in quarantine for a long time increases the probability to show PTSD symptoms (24). Similarly, a study conducted on people in quarantine in Toronto found the rate of depression at a very high level of $31.2 \%$ (25). A study examining depression symptoms in hospital workers found a high rate of depression symptoms in $9 \%$ of employees 3 years after the epidemic. About $60 \%$ of those with high depression symptoms remained in quarantine, while only $15 \%$ of those with low depression symptoms had a history of quarantine (7). Another study in China found that being quarantined in healthcare workers is a predictor of PTSD development even after 3 years (25).

Those who are quarantined continue to complain of many mental problems, even if they do not get sick and long after their quarantine ends. One study found that quarantine was a predictor for PTSD in hospital workers even after 3 years (25).

\section{The Collapse of Social Support Systems}

Medical professionals have long recognized the importance of strong social networks on mental health. Epidemics leave people feeling isolated and vulnerable by breaking down social support structures at a time when they are most needed. When faced 
with an epidemic, many places where people receive social support, such as mosques, schools, and workplaces, can be closed to slow the rate of spread. Even minor social interactions, such as visiting a friend's home, may have been stopped for fear of encountering the disease.

In his book The Great Influenza, American historian John M. Barry explains the major breakdown in post-epidemic support systems as follows: "The fear began to destroy the sociality of the city. Trust was broken. Faced with public catastrophe, not only tension but anger, not just blaming someone or protecting their own interests, but signs of active selfishness began" (26). The destruction of social support can extend to the basic unit of the social structure, the family, which is the closest and most important bond of the individual. Manuel Fontaine, UNICEF Regional Director for West and Central Africa, observed that many families even abandoned their children due to fear and stigma during the Ebola epidemic in West Africa and said "Fear of Ebola exposure is stronger than family ties in some communities" (27).

Individuals obtain strength from social support systems as well as personal coping and defense mechanisms against psychological threats especially in times of stress and trauma. The perceived threat and the possibility of encountering its consequences are tried to be balanced with coping and support systems. A prospective longitudinal study conducted after an accident has shown that access to social support reduces subsequent post-traumatic symptomatology (28). During the SARS epidemic, it has been reported that coping behaviors that disperse negative emotions with open communication in a supportive environment caused people to accept the situation better and reduce psychological morbidity (29). On the other hand, if support systems are not successful and balance cannot be established, cognitive distortions such as insufficiency, helplessness, and uncertainty increase, and serious mental disorders are triggered. A study showed that social network changes after the earthquake continue to be a risk factor for psychiatric morbidity even after 1 year (30).

\section{Stigmatization}

Stigmatization is another mechanism of social isolation caused by epidemic diseases and has an important role in the formation of mental disorders. Especially in infectious diseases, people are stigmatized because of an association with the disease; Stereotypes circulate with unrealistic or distorted information, and targeted people are discriminated against. People and communities begin to exclude and perceive threats from each other due to feelings of fear, insecurity, and exclusion. This perception causes the stigmatized individual to become lonely and sometimes leads to symptoms of anxiety, social withdrawal, pessimism, hopelessness, inadequacy, helplessness, and the emergence of feelings such as anger, anxiety, and sadness. These feelings and thoughts are known to trigger mental disorders.

The most obvious target of stigmatization is sick people and those who are quarantined. But sometimes the entire population or community can be targeted, as were Asian Americans during SARS, West Africans during Ebola, Haitians and homosexuals in the early AIDS period. During the COVID-19 pandemic, especially the elderly, people from the Far East, people from abroad, and healthcare professionals were targeted. Healthcare professionals are among the most excluded and stigmatized groups, as it is known that they have close contact with patients. Health workers who are in close contact with patients can be excluded, people who send good messages from afar may display discriminatory behaviors when they see them shopping, in the apartment, at home even when necessary social distance and adequate precautions are taken. Common examples of exclusion include residents of neighborhood or their apartment avoiding contact and not inviting them to social environments.

Sometimes patients may escape from the healthcare system for fear of stigmatization. This has been a very important problem in HIV or AIDS patients who avoided tests and treatment due to stigma.

\section{Epidemiology of Mental Disorders During the Pandemic}

Infectious disease epidemics often affect body health and combat focuses on attempts to slow the rate of infection and heal those who are sick. However, even if the pathogenesis does not always involve the brain in these infections, pandemics generally cause mental illness. It is known that events that scare the person a lot, leave them in horror, and create feelings of helplessness, cause long-lasting mental problems. Therefore, epidemics are almost always accompanied by a silent epidemic of mental disorders. Several studies demonstrated that various psychiatric disorders, especially trauma and stress-related disorders, sleep disorders, alcohol-substance use disorders, depression, and anxiety disorders occur in pandemics. Rogers et al. (31) recently conducted a metaanalysis of 65 peer-reviewed articles which were selected among 1963 articles; the most common psychiatric problems observed in patients admitted due to SARS and MERS during the acute period were confusion (27.9\%), depressive mood $(32.6 \%)$, anxiety (35.7\%), memory impairment (34.1\%), and insomnia (41.9\%). After the pandemic the prevalence of PTSD was $32.2 \%$, depression was $14.9 \%$, and anxiety disorders was $14.8 \%$ (31). Exacerbation of preexisting psychiatric disorders is also common (32). Children and adolescents may show regression, social isolation, and aggressive behavior due to misinterpretation of the "acting-out" defense. Several previous studies indicated that the relationship between catastrophic life events and eventrelated loss in resources is important. It is noted that the higher the number of casualties, the higher the risk of mental problems. Loss of resources is a key concept for protection as well as for mental problems $(33,34)$. Fighting mental disorders during epidemics does not only provide psychological well-being; as these disorders may slow down the efforts to tackle pandemic, this may also affect the course of the pandemic.

\section{Health Anxiety}

Fear of COVID-19 or other illnesses can be considered as a special type of anxiety called health anxiety. Taylor and Asmundson (35) describe health anxiety as a beneficial response to physical illnesses to a certain extent. Normal levels of anxiety ensure that necessary measures are taken to prevent or alleviate 
illness. However, when health anxiety is chronic and excessive or significantly greater than the severity of the health-related threat anxiety may be a problem (36). This type of anxiety leads to disability and is a common symptom in many psychiatric disorders such as hypochondriasis, OCD, panic disorder, and specific phobias. Patients with extreme health anxiety constantly seek assurances that they are not sick, but when this guarantee is given, they cannot be comfortable for a long time and their anxiety increases gradually (35). They often check their body and review medical resources frequently to confirm the illness. Excessive mental engagement with health anxiety leads to the development of bodily sensations and symptoms associated with anxiety, which leads to a further increase of anxiety in a vicious circle.

\section{Obsessive-compulsive Disorder (OCD)}

It is especially important during a pandemic. Anxiety symptoms can easily transform into fear of illness, and extreme-pathological avoidance can be developed to avoid contact with the disease. Contamination fears are the most common types of obsession in $\operatorname{OCD}(14,37)$. Also, a common obsessive-compulsive belief is an exaggeration of the threat. In contamination type OCD, this exaggeration leads a person to develop obsessions about being sick and contaminating others (38). Probably, after the COVID-19 pandemic, both new OCD cases will emerge and many of the old OCD patients will make this the main complaint. Exaggerated attempts, such as avoiding contact with the disease and testing for diagnosis, will keep clinicians busy during this period. Press is a determinant in the nature of this relationship.

It is important to remember that obsessive beliefs are not specific to OCD and can be seen in other anxiety disorders. Finally, pandemic-related fears are reported to be more common in individuals with disgust sensitivity (39).

\section{Depression}

Depression is one of the common disturbances after mental traumas. The most common symptoms of depression are loss of interest, fatigue, depressed mood, sleep and appetite disturbance, and inability to enjoy life. Depression can occur for the first time after a mental trauma, or a recurrence may occur in people who have had depression before. In a study conducted in a hospital structured for SARS in Taiwan, depression rates were found to be higher in nurses working in SARS units compared to nurses working in other units (38.5\% vs. $6.7 \%)$. No significant difference was found between the nurses working in the normal SARS clinic and the intensive care SARS clinic (40).

\section{Acute Stress Disorder and Posttraumatic Stress Disorder}

Although the symptoms are the same in these disorders that arise in relation to the trauma, differential diagnosis is made on the basis of time. Conditions that occur and improve within 1 month after trauma are diagnosed as ASD, and symptoms lasting longer than 1 month are diagnosed as Post Traumatic Stress Disorder (PTSD). Generally, a relationship between the severity of the trauma and the quality and quantity of the symptom cluster is defined.

PTSD was initially named as a soldier's heart due to cardiac symptoms observed in soldiers during the American civil war. Later, it was used to define mostly traumatic reactions of soldiers as the irritable heart and Shell shock. Although similar symptoms were observed in Nazi concentration camp survivors after the Second World War and after the atomic bomb in Japan, this situation, which is generally ignored, was included as a diagnosis of PTSD in the third edition of DSM in 1978 after the Vietnam War. Later, in the revised form, the traumas that could lead to PTSD were defined as "The person has experienced an event that could be a source of distress for almost everyone, far beyond the usual human life" $(14,41)$.

In DSM-5, the last edition of DSM published in 2013, the trauma required for the diagnosis of PTSD was described as "experiencing death, serious injury or sexual assault in a real or threatening way". For the diagnosis, other than directly experiencing traumatic events, seeing the events that happened to others directly, witnessing, learning that traumatic events have happened to a family relative or friend, and even repetitive or excessive encounters with disturbing details of traumatic events may be sufficient. This last point is particularly valid for healthcare professionals. For the diagnosis of PTSD, there should be symptoms in three main symptom clusters, which consist of somatic symptoms related to experiencing trauma day and night, avoiding stimuli reminding trauma, negative changes in cognition and mood, and increased responses of the autonomic nervous system (14).

It is reported that $60-80 \%$ of those with a lifetime diagnosis of PTSD develop at least one other psychiatric disorder throughout their life. The most common comorbid diagnoses in men are alcohol abuse and addiction, major depression, conduct disorder, and substance abuse. In women, the most common diagnoses are major depression, phobia, alcohol abuse, and addiction. People who have previously had a mental illness have a higher risk of recurrence of those diseases after trauma. If there is a second mental illness other than PTSD, both the distress experienced by the person and the loss of workforce increase, and it requires more intense and longer-term treatment (14).

\section{Other Disorders}

Confusion is the most common psychiatric finding in the acute phase of SARS and MERS, which suggests that delirium is common. Especially in intensive care patients, delirium syndromes, which are marked by impaired consciousness, orientation, and attention, are very common and make patient care difficult. Mania and acute psychosis have been reported in a small number of patients. Sleep disorders are very common conditions (31). A meta-analysis reported ongoing problems in more than $15 \%$ of patients after the recovery of infections, especially sleep disturbance, frequent recall of traumatic memories, emotional lability, concentration weakness, fatigue, and memory weakness (31). 


\section{Impacts on Healthcare Professionals and the Healthcare System}

Epidemics have many negative effects on the mental health system as well as on the physical health system. Healthcare workers have the largest share of these negative effects. Psychiatric complaints of healthcare professionals increase significantly due to both being the occupational group with the most contact with patients and the severe working conditions during the epidemic. Healthcare workers dealing with the diagnosis and treatment of COVID-19 were faced more with additional stress sources such as limited protective equipment, lack of rest periods and sleep, physical isolation (even outside working hours), constant stimulation with infection control procedures, and disappearance of spontaneity. The conflict between the priorities of the health authority and the demands of patients and their families directly targets healthcare professionals. Also, serving traumatized people can itself be traumatic. This is called "secondary trauma". All healthcare professionals, from security personnel to cleaners, from doctors to administrative personnel, are at risk of secondary trauma during times of crisis and disaster. Secondary trauma is also known to increase the risk of burnout.

With the contribution of all risk factors, it is certain that working in the hospital or other health institutions during the epidemic creates stress and trauma in at least some of the healthcare workers. According to many studies, factors such as premorbid personality structure, traumatic events experienced in childhood, and presence of another mental disorder affect the behaviors of intense reaction to trauma and PTSD does not develop in 80$90 \%$ of people who are exposed to trauma (41). However, in outbreaks such as SARS and COVID, being in an intense struggle with a disease that spreads rapidly on a global scale and has a high mortality, regardless of these variables, poses a high enough risk. The prevalence of PTSD and other psychiatric disorders in healthcare workers increases significantly, especially when the agent is not fully recognized, the mode and cause of transition is not known, and the prognosis is uncertain (42). In addition, it is known that healthcare workers are exposed to more exclusion and stigmatization as they are thought to be more likely to be contagious than the general population, they also exhibit more avoidance behaviors from patients and crowded environments, experience more income loss, and all of these increase the risk.

In studies conducted during the SARS epidemic in Taiwan and Singapore, psychiatric morbidity rates in healthcare workers were found to vary between $20 \%$ to $75.3 \%(29,42-44)$. Although different rates are related to factors such as the severity of the epidemic, time to get it under control, or the difference in the scales used, there are very high rates compared to the general population. In studies conducted after the same epidemic in Hong Kong, Singapore, and Canada, emotional disturbances were found in $18 \%$ to $57 \%$ of healthcare workers during and immediately after the epidemic $(43,45,46)$. The increase in psychiatric morbidity continues after the epidemic is brought under control. A study of Toronto hospital staff in Canada showed that depression attacks and new cases of PTSD were still occurring 1-2 years after the outbreak (32). A study comparing
SARS patients with healthy controls found that patients who were healthcare workers reported more fatigue and health anxiety than others (16).

A very recent meta-analysis by Kisely et al. (47) reviewing 59 publications on healthcare workers involved in outbreaks such as SARS, MERS, and Ebola found that ASD, PTSD (odds ratio $1.71,95 \%$ confidence interval 1.28), and psychological distress $(1.74,1.50-2.03)$ were at a high rate in healthcare workers exposed to infected patients. The most common risk factors for psychological distress were being young, female gender, lack of experience, having a dependent child, and having an infected family member. Also, a long duration of quarantine, lack of support, insufficient knowledge about the pandemic, and perception of stigmatizing attitudes towards healthcare personnel from neighbors and relatives are risk factors. History of psychological or physical illness in the periods before the epidemic was also important. Within professional groups, nurses were generally found to have a higher risk than doctors (47).

Many studies reviewed by Kisely et al. (47) demonstrated that open communication, access to appropriate personal protection, good education and adequate experience on infectious disease, appropriate rest periods, access to appropriate protective equipment, practical support, and psychological support from the family and the community helped reduce morbidity. Access to psychological interventions and the existence of protocols supporting staff had a very protective effect. Besides, frequent review and renewal of procedures to reduce the high risk of infection and keeping a low density at wards were shown to be effective. Keeping working hours short, resting during breaks, regular supply of food and daily living equipment, and opportunities to meet with families, albeit remotely, were defined as organizational supports that would reduce the risk.

Since medical professionals with mental disorders will be less productive, this will lead to a weakening of the fight against the pandemic. In fatal and easily transmitted infections, a large number of healthcare workers can get sick, die, and this can put the system into great difficulty. During times when the need for mental health services is greatest, the mental epidemic may reduce the health system's ability to cope with the epidemic. Healthcare professionals may be overly preoccupied with efforts to cope with pandemic while neglecting other medical conditions. In addition, patients may escape from healthcare facilities with fear of exposure to infection. Reduced access to mental health services may increase stress in health systems.

Especially in crisis situations, factors such as prolongation of working hours, excessive workload, the dangerous working environment can cause excessive consumption of energy and create a risk for burnout syndrome. Although it is not a defined disorder in systems such as DSM, Burnout syndrome, which is defined especially in professionals such as healthcare professionals, is a condition characterized by loss of motivation, interest, and desire, as well as a general loss of energy, negative feelings and thoughts about himself, inadequacy and a sense of failure. The COVID-19 outbreak poses a risk of burnout as it 
creates a crisis in the health system. The WHO recommendations to the institutions to protect from burn-out syndrome includes good communication, multidisciplinary team meetings, implementation of a "partner" system which is based on the principle of matching employees who will take part in disasters or mass traumas, rotational work order and participatory techniques in which humor is widely used, discussing problems or experiences with colleagues, increasing the processes of supervision/consultation with colleagues.

\section{Conclusion and Recommendations}

Our previous experiences show that we will face an important risk of mental disorders after the pandemic. While efforts to organize the health system in a way to cope with the epidemic continue, it is also important to mature mental support and treatment programs. Especially healthcare professionals should be supported by organizational systems for their own mental health and quality of the service they will provide to people. Working and resting conditions should be improved, shortage of medical and protective equipment should be avoided, and they should have more opportunities to be with their families. In a crisis situation, additional financial problems should not be raised.

Similar improvements and measures are also recommended for the general population. People may lose their jobs, financial savings, or relatives during such disasters, and may have to stay in quarantine or isolation for long periods without friend or family support. In this case, the person feels helpless and hopeless, the distress levels gradually increase. Therefore, communication and correct information channels should be kept open. It is important for traumatized people to communicate with traumatized people like themselves, to talk about events, and to reveal their feelings, both to relieve their pain and to feel less alone. Different types of assistance and approaches to other affected persons can contribute to the traumatized person's recovery process. The benefits of written-visual media in terms of accurate information and social media in terms of support systems are certain. However, the media's sometimes exaggerated and intense news of uncertainty and despair can lead to an increase in feelings of anxiety and panic at the society level. Fears, worries, and false beliefs spread rapidly among individuals as well as in local communities and in public. Some authors believe that excessive exposure to the media increases distress levels and suggest to reduce the use of traditional and social media during these periods. It is very important to regulate sleep, nutrition, and rest functions during epidemic days to combat both infection and mental stress. It is recommended that every family should be encouraged to develop a family plan in order to access medical help in outbreaks and to cope with all aspects of the epidemic, as for other disasters. Seeking, forming and sharing new social support bonds, strengthening old bonds and seeking ways to help others are positive actions for mental health. It is recommended not to make sudden and major life changes during and immediately after the epidemic, and to avoid negative coping strategies such as alcohol-substance, or drug abuse. As with community-level planning, time should be planned for returning to normal life at a personal and family level. Finally, if the perceived stress and psychological problems last more than 2-3 weeks, ways to get mental help should be sought $(18,47,48)$.

Peer-review: Externally peer reviewed.

Financial Disclosure: This work was supported by Abdi İbrahim Pharmaceuticals.

\section{References}

1. World Health Organization. The World Health Report 2004: changing history. Geneva: WHO; 2004.

2. Ashour HM, Elkhatib WF, Rahman MM, Elshabrawy HA. Insights into the recent 2019 Novel Coronavirus (SARS-CoV-2) in light of past numan coronavirus outbreaks. Pathogens 2020 Mar 4;9:186.

3. Novel Swine-Origin Influenza A (H1N1) Virus Investigation Team, Dawood FS, Jain S, Finelli L, Shaw MW, Lindstrom S, et al. Emergence of a novel swine-origin influenza A (H1N1) virus in humans. N Engl J Med 2009;360:2605-15.

4. Feldmann H, Jones S, Klenk HD, Schnittler HJ. Ebola virus: From discovery to vaccine. Nat Rev Immunol 2003;3:677-85.

5. Centers for Disease Control and Prevention, National Center for Emerging and Zoonotic Infectious Diseases (NCEZID), Division of Global Migration and Quarantine (DGMQ). Quarantine and Isolation. 2020. Last Accessed Date: 19.05.2020. Available from: https://www. cdc.gov/quarantine/index.html.

6. Qiu J, Shen B, Zhao M, Wang Z, Xie B, Xu Y. A nationwide survey of psychological distress among Chinese people in the COVID-19 epidemic: Implications and policy recommendations. Gen Psychiatr 2020;33:100213.

7. Liu X, Kakade M, Fuller CJ, Fan B, Fang Y, Kong J, et al. Depression after exposure to stressful events: Lessons learned from the severe acute respiratory syndrome epidemic. Compr Psychiatry 2012;53:15-23.

8. Sheng B, Cheng SK, Lau KK, Li HL, Chan EL. The effects of disease severity, use of corticosteroids and social factors on neuropsychiatric complaints in severe acute respiratory syndrome (SARS) patients at acute and convalescent phases. Eur Psychiatry 2005;20:236-42.

9. Chou FH, Su TT, Chou P, Ou-Yang WC, Lu MK, Chien IC. Survey of psychiatric disorders in a Taiwanese village population six months after a major earthquake. J Formos Med Assoc 2005;104:308-17.

10. Stein MB. Coronavirus disease 2019 (COVID-19): Psychiatric symptoms and disorders. UpToDate. May 19, 2020.

11. Sadock BJ, Sadock VA. Kaplan \& Sadock's Synopsis of Psychiatry: Behavioral Sciences/Clinical Psychiatry. 10th ed. Philadelphia, Lippincott Williams and Wilkins. 2007;814.

12. Lyon BL. Stress, coping, and health: a conceptual overview: In Handbook of Stress, Coping, and Health: Implications for Nursing Research, Theory and Practice; 2000.p.2-20.

13. Herman JL. Complex PTSD: A syndrome in survivors of prolonged and repeated trauma. Journal of Traumatic Stress 1992;5: 377-91.

14. American Psychiatric Association. Diagnostic and Statistical Manual of Mental Disorders. 5th ed. Washington, DC: American Psychiatric Association; 2013.

15. Kubler-Ross E. On death and Dying, New York: The Macmillan Company; 1969. 
16. Chua SE, Cheung V, McAlonan GM, Cheung C, Wong JW, Cheung EP, et al. Stress and psychological impact on SARS patients during the outbreak. Can J Psychiatry 2004;49:385-90.

17. Lee AM, Wong JG, McAlonan GM, Cheung V, Cheung C, Sham PC, et al. Stress and psychological distress among SARS survivors 1 year after the outbreak. Can J Psychiatry 2007;52:233-40.

18. WHO. Mental Health in Emergencies. 2019. Available from: https://www.who.int/news-room/fact-sheets/detail/mental-health-inemergencies.

19. Berehulak D. Portraits: Braving Ebola. New York Times, October 31, 2014.

20. Barbisch D, Koenig KL, Shih FY. Is there a case for quarantine? Perspectives from SARS to ebola. Disaster Med Public Health Prep 2015;9:547-53.

21. Miles SH. Kaci Hickox: Public health and the politics of fear. Am J Bioeth 2015;15:17-9.

22. Rubin GJ, Wessely S. The psychological effects of quarantining a city. BMJ 2020;368:313.

23. Bai Y, Lin CC, Lin CY, Chen JY, Chue CM, Chou P. Survey of stress reactions among health care workers involved with the SARS outbreak. Psychiatr Serv 2004;55:1055-7.

24. Hawryluck L, Gold WL, Robinson S, Pogorski S, Galea S, Styra R. SARS control and psychological effects of quarantine, Toronto, Canada. Emerg Infect Dis 2004;10:1206-12.

25. Wu P, Fang Y, Guan Z, Fan B, Kong J, Yao Z, et al. The psychological impact of the SARS epidemic on hospital employees in China: Exposure, risk perception, and altruistic acceptance of risk. Can J Psychiatry 2009;54:302-11.

26. Barry JM. The great influenza: The epic story of the deadliest plague in history. New York: Viking Books; 2004.p.546.

27. Goldberg E. Ebola nearly wiped out this entire family. Now sisters are raising 6 orphans. IMPACT 11/24/2014.

28. Joseph S, Yule W, Williams R, Andrews B. Crisis support in the aftermath of disaster: a longitudinal perspective. Br J Clin Psychol 1993;32:177-85.

29. Sim K, Chong PN, Chan YH, Soon WS. Severe acute respiratory syndrome-related psychiatric and posttraumatic morbidities and coping responses in medical staff within a primary health care setting in Singapore. J Clin Psychiatry 2004;65:1120-7.

30. Chou FH, Chou P, Su TT, Ou-Yang WC, Chien IC, Lu MK, et al. Quality of life and related risk factors in a taiwanese village population 21 months after an earthquake. Aust N Z J Psychiatry 2004;38:358-64.

31. Rogers JP, Chesney E, Oliver D, Pollak TA, McGuire P, Fusar-Poli P, et al. Psychiatric and neuropsychiatric presentations associated with severe coronavirus infections: a systematic review and meta-analysis with comparison to the COVID-19 pandemic. Lancet Psychiatry 2020;7:611-27.

32. Lancee WJ, Maunder RG, Goldbloom DS; Coauthors for the Impact of SARS study. Prevalence of psychiatric disorders among Toronto hospital workers one to two years after the SARS outbreak. Psychiatr Serv 2008;59:91-5.
33. Freedy JR, Saladin ME, Kilpatrick DG, Resnick HS, Saunders BE. Understanding acute psychological distress following natural disaster. J Trauma Stress 1994;7:257-73.

34. Hobfoll SE. Conservation of resources. A new attempt at conceptualizing stress. Am Psychol 1989;44:513-24.

35. Taylor S, Asmundson GJG. Treating health anxiety: A cognitivebehavioral approach. 1st ed. New York: The Guilford Press; 2004.

36. Taylor S, McKay D, Abramowitz J. Hypochondriasis and health-related anxiety. In: Sturmey P, Herson M, editors. Handbook of evidencebased practice in clinical psychology. New York: Wiley; 2012.p.603-19.

37. Ball SG, Baer L, Otto MW. Symptom subtypes of obsessive-compulsive disorder in behavioral treatment studies: A quantitative review. Behav Res Ther 1996;34:47-51.

38. Cisler JM, Brady RE, Olatunji BO, Lohr JM. Disgust and Obsessive Beliefs in Contamination-related OCD. Cognit Ther Res 2010;34:43948.

39. Brand J, McKay D, Wheaton MG, Abramowitz JS. The relationship between obsessive compulsive beliefs and symptoms, anxiety and disgust sensitivity, and Swine Flu fears. J Obsessive Compuls Relat Disord 2013;2:200-6.

40. Su TP, Lien TC, Yang CY, Su YL, Wang JH, Tsai SL, et al. Prevalence of psychiatric morbidity and psychological adaptation of the nurses in a structured SARS caring unit during outbreak: A prospective and periodic assessment study in Taiwan. J Psychiatr Res 2007;41:119-30.

41. Kessler RC, Sonnega A, Bromet E, Hughes M, Nelson CB. Posttraumatic stress disorder in the National Comorbidity Survey. Arch Gen Psychiatry 1995;52:1048-60.

42. Liu CY, Yang YZ, Zhang XM, Xu X, Dou QL, Zhang WW, et al. The prevalence and influencing factors in anxiety in medical workers fighting COVID-19 in China: A cross-sectional survey. Epidemiol Infect 2020;148:98.

43. Chan AO, Huak CY. Psychological impact of the 2003 severe acute respiratory syndrome outbreak on health care workers in a medium size regional general hospital in Singapore. Occup Med (Lond) 2004;54:190-6.

44. Chong MY, Wang WC, Hsieh WC, Lee CY, Chiu NM, Yeh WC, et al. Psychological impact of severe acute respiratory syndrome on health workers in a tertiary hospital. Br J Psychiatry 2004;185:127-33.

45. Tam CW, Pang EP, Lam LC, Chiu HF. Severe acute respiratory syndrome (SARS) in Hong Kong in 2003: Stress and psychological impact among frontline healthcare workers. Psychol Med 2004;34:1197-204.

46. Maunder RG, Lancee WJ, Rourke S, Hunter JJ, Goldbloom D, Balderson K, et al. Factors associated with the psychological impact of severe acute respiratory syndrome on nurses and other hospital workers in Toronto. Psychosom Med 2004;66:938-42.

47. Kisely S, Warren N, McMahon L, Dalais C, Henry I, Siskind D. Occurrence, prevention, and management of the psychological effects of emerging virus outbreaks on healthcare workers: Rapid review and meta-analysis. BMJ 2020;369:1642.

48. Brooks SK, Webster RK, Smith LE, Woodland L, Wessely S, Greenberg $\mathrm{N}$, et al. The psychological impact of quarantine and how to reduce it: Rapid review of the evidence. Lancet 2020;395:912-20. 